Јанко Рамач

Универзитет у Новом Саду

Филозофски факултет

Одсек за русинистику

ramacjanko@gmail.com
Оригинални научни рад

примљено: 6. јун 2011

прихваћено: 1. октобар 2011

\title{
ФЕДОР ЛАБОШ И ЊЕГОВО ДЕЛО У ИСТОРИОГРАФИЈИ О РУСИНИМА У ЈУЖНОЈ УГАРСКОЈ*
}

Сажетак: Федор Лабош, по струци економиста, цео живот је истраживао историју Русина у Јужној Угарској. Рукопис његове историје Русина у Бачкој, Срему и Славонији (1745-1918), који обухвата и преглед историје Русина у карпатском ареалу пре досељавања у Бачку, био је већ од педесетих година прошлог века доступан неким истраживачима који су га обилно користили. Лабошев рукопис је био објављен тек после његове смрти са неким недостацима који сведоче о ауторовој одсутности приликом објављивања рукописа. У раду се критички сагледава ово значајно дело за историографију Русина у Јужној Угарској до 1918. године.

Кључне речи: Федор Лабош, историографија о Русинима, Русини у Јужној Угарској, гркокатолици, православни.

Прва обимнија историја Русина у Јужној Угарској / Југославији појавила се 1977. године, ${ }^{1}$ мада је рукопис историје Русина Бачке Срема и Славоније (17451918) Федора Лабоша већ од педесетих година био доступан неким истраживачима, тако да су га користили Онуфриј Тимко ${ }^{2}$ и Славко Гавриловић. ${ }^{3}$ Лабош је свој

\footnotetext{
* Рад је настао као фазни резултат републичког пројекта број 177002 под називом Војвођански простор у контексту европске историје.

${ }^{1}$ Ово колективно дело сарадника Института за историју Војводине под заједничким насловом Iz istorije vojvođanskih Rusina do 1941. godine објављено је у Godišnjaku Društva istoričara Vojvodine за 1977. годину и садржи пет посебних прилога: Slavko Gavrilović, Rusini u Bačkoj i Sremu od sredine XVIII do sredine XIX veka, стр. 153-215; Branislav Vranešević, Rusini u borbi za nacionalni opstanak 1848-1890, стр. 217-253; Arpad Lebl, Rusini od 1890. do 1918, стр. 255-273; Nikola Gaćeša, Rusini između dva svetska rata, cтр. 275-306 ; Milenko Palić, Rusini u radničkom pokretu do 1941. godine, стр. 309-328.

${ }^{2}$ Онуфриј Тимко, Насељеници Руског Крстура и Куиуре, Зборник Матице српске за друштвене науке, бр. 50, Нови Сад 1968, 130-142. Ту Тимко наводи Лабошев рукопис: Dr F. Laboš, Seljidba od Karpatoch do Bački, 1950, 50.

${ }^{3}$ Slavko Gavrilović, Rusini u Bačkoj i Sremu od sredine XVIII do sredine XIX veka, Godišnjak Društva istoričara Vojvodine, Novi Sad 1977, 153-215. Гавриловић се у овој студији често позива на Лабошев рукопис и
} 
рукопис годинама проширивао и допуњавао, а књига је објављена тек 1979. године, после његове смрти. ${ }^{4}$

Федор Лабош је по образовању био економиста и стекао је докторат из економских наука, али се од студентских дана бавио истраживањем историје Русина у Јужној Угарској. Главно његово дело је наведена књига, а објавио је још неколико мањих чланака који су практично делови те књиге објављени пре њеног појављивања.

У историографији о Русинима у Јужној Угарској до 1918. године наведено дело Ф. Лабоша је било доста коришћено и цитирано, али до сада, осим углавном пригодних приказа, није било критички сагледано.

Свестан да је о периоду прошлости Русина пре њиховог досељавања у Јужну Угарску средином 18. века било веома мало информација међу овдашњим Русинима, Ф. Лабош је у свом делу желео да прикаже и тај део њихове историје. Покушао је да на тридесетак страна да синтетички преглед прошлости Русина у карпатском ареалу на основу познате литературе на мађарском, немачком и украјинском језику. Добра Лабошева замисао да у књизи о прошлости Русина у Јужној Угарској до 1918. године да сажет приказ њиховог живота у старом завичају пре досељавања у Јужну Угарску није изведена на најбољи начин, јер аутор није успео да на основу релевантне и доста обимне литературе коју је користио направи добар синтетички преглед. Често се просто губио у мноштву података настојећи да да̂ што више примера и појединачних описа о тешком животу Русина, о многобројним феудалним обавезама, о антифеудалним бунама, устанцима, ратовима, одмаздама и пустошењима, која су допринела њиховим честим и масовним миграцијама на територији североисточне Угарске и Галиције. Тај део је најмање оригиналан и уједно нешто слабији део његове књиге, али и такав је користан за обичног читаоца, јер пружа одређену слику о животу Русина у карпатском ареалу до почетка 18 . века.

Лабош указује да је доста интензивна миграција Русина из североисточних жупанија Угарске јужније почела знатно пре почетка организованог насељавања Русина у Бачку средином 18. века наводећи податке из пописа становништва Угарске за насеља у којима су живели гркокатолици на територији која се у облику клина спуштала од североисточних жупанија све до Сегедина и Макоа. Неки од ових миграната, тражећи погодније услове за живот, прелазили су реку Мориш и настањивали се у појединим насељима у Банату: у Мокрину, Иђошу, Руском Селу и у другим местима. Државна статистика још средином 19. века овде бележи известан број гркокатолика, који тада већ нису били записивани као Русини. ${ }^{5}$ У историографији и у познатим изворима нема података о контакту Русина у Бачкој, у Крстуру, Куцури или у другим местима, у којима су живели у мањем броју, са овим

преузима из њега многе податке. Он наводи наслов Лабошевог рукописа: Od Gornjici do Bačkej и каже да је рађен претежно на грађи бившег коморског архива у Сомбору, доста трезвено и објективно.

${ }^{4}$ Федор Лабош, История Русинох Бачкей, Сриму и Славониї 1745-1918, Союз Русинох и Українцох Горватскей, Вуковар 1979, 299.

${ }^{5}$ Федор Лабош, нав. дело, 59. Ту он наводи да је по државној статистици из 1857. године у срезу Велики Св. Никола било 1559, а у срезу Турска Кањижа 558 гркокатолика. 
гркокатолицима у Банату. Део миграната, који су прешли Тису, настављали су пут и задржавали се или настањивали у појединим насељима у Бачкој: у Мартоношу, Бечеју, Шовама, Кули, Обровцу, а неки су се заустављали чак у Срему. ${ }^{6}$

У попису становника Куле из 1746. године забележено је 14 русинских породица. $^{7}$ Славко Гавриловић сматра да у Крстуру до 1748. године није било Русина, јер се он тада спомиње као ненасељена пустара. ${ }^{8}$ Лабош наводи да је у Крстуру 1746. године већ било 78 русинских породица, ${ }^{9}$ да је до краја 1750 . у селу било око 200 породица, а да се 1751. године доселило још 120 породица. ${ }^{10}$ Међутим, коморски администратор Редл, који је сигурно имао тачне податке о Русинима на Кулском коморском властелинству, наводи да се приликом оснивања коморског насеља Велики Крстур ту преселило 19 русинских породила из Куле. ${ }^{11}$ У попису становника Крстура из 1753. године прво је пописано 19 породица које су се преселиле из Куле, после њих још 13 породица које су се доселиле 1751, и на крају 28 породица које су се доселиле из разних места током 1752. године. ${ }^{12}$ На попису 1756. године забележено је укупно 127 породица. ${ }^{13}$ У сваком случају то је много мањи број од оног до ког је Лабош дошао више разним претпоставкама него поузданим подацима из извора. Зато је он истицао да се један део русинских досељеника, незадовољних овдашњим привредним и климатским приликама вратио у стари завичај, а да су се многи преселили у нека суседна или друга насеља: у Обровац, Шајкаш, Варадин итд., где су били као национална и религијска мањина и вероватно су се временом асимиловали. ${ }^{14}$

У неким изворима и у литератури наводи се да је Мако, градић недалеко од Сегедина, био за неке Русине који су се крајем четрдесетих и педесетих година 18. века досељавали у Крстур последња станица где су се извесно време задржавали. ${ }^{15}$

\footnotetext{
${ }^{7}$ Федор Лабош, нав. дело, 59-60, 189-197. Ову своју тврдњу Лабош поткрепљује подацима из изјава појединаца пред судским властима у Крстуру 1757. године у којима они тачно наводе када и како су дошли у Бачку.

${ }^{7}$ Славко Гавриловић, нав. дело, 155; Мирон Жирош, Бачванско-сримски Руснаци дома и у швеце 17451991, т. І, Нови Сад, 1997, 27-28.

${ }^{8}$ Славко Гавриловић, нав. дело, 155.

${ }^{9}$ Федор Лабош, нав. дело, 62, али он овде не наводи извор за ову тврдњу; Онуфрије Тимко, нав. дело, 130 - наводи исти податак, и мада не наводи извор, из цитата на мађарском језику се види да је текст из монографије Бач-бодрошке жупаније: Samu Borovszky, Bacs Bodrog vármegye, t. I, Budapest 1909, 102: међутим, ту се наводи да је у Кулу 1746. године стигло 11 русинских породица из околине Мишколца и да је крајем 1746. године у Кули било 78 породица, заједно српских и русинских, а не 78 русинских породица.

${ }^{10}$ Федор Лабош, нав. дело, 67.

${ }^{11}$ Државни архив у Будимпешти (Országos levéltár, Budapest), даље: ДАБ: Е-25, Informationes Cameralis administrationis Bacsiensis, Redl - Извештај коморског администратора Редла Угарској дворској комори од 7. 09. 1756. године.

12 Славко Гавриловић, нав. дело, 155; Мирон Жирош, Бачванско-сримски Руснащи дома и у швеце 17451991, т. I, Нови Сад 1997, 29-50. Ту Жирош прилаже копију пописа становника Крстура из 1753. године.

${ }^{13}$ Славко Гавриловић, нав. дело, 156; Мирон Жирош, нав. дело, 33-38.

${ }^{14}$ Федор Лабош, нав. дело, 68.

${ }^{15}$ Володимир Гнатюк, Руски населєня у Бачкей, у: Володимир Гнатюк, Етнографски материялни 3 Угорскей Руси, т. V, Руске слово, Нови Сад 1986, 83. Ту је Хнатјук забележио у Крстуру 1897. године
} 
Лабош то поткрепљује подацима из примарних извора. ${ }^{16}$ Ипак, не може се без резерве прихватити Лабошева тврдња да су русинским досељеницима у Макоу замењивали словенска презимена мађарским и да су они стизали у Крстур са новим, мађарским презименима. Наиме, у матичним књигама рођених, венчаних и умрлих које се чувају у тој парохији кроз цео 19. век многи гркокатолици имали су чиста словенска презимена и тада кад се више нису изјашњавали као Русини него као Мађари. ${ }^{17}$ Зато нема основе тврдити да су оној групи Русина која се само неколико месеци задржала у Макоу одмах промењена презимена. Истина, многим Русинима у Бачкој су током 18. и 19. века замењивана русинска/словенска презимена мађарским на разне начине: понекад је промењен само облик, на пример: Паљинчар > Паљинкаш (Pálinkás), Мучонски > Мучоњи (Mucsonyi), или се значење презимена буквално преводи: Галузка (галузка - укр. грана) > Фа (fa - мађ). дрво); Мељник (мельник - укр. млинар) > Молнар (molnár - мађ) млинар), или једноставном заменом русинских/словенских презимена мађарским. ${ }^{18}$

Лабош сматра да коморски администратор Јозеф де Редл није тражио дозволу од централних коморских или државних власти да на коморску пустару Велики Крстур насели гркокатолике Русине из североисточних жупанија Угарске, него да је то урадио по својој личној компетенцији. ${ }^{19}$ Међутим, Владимир Биљња је истицао да је Бечки двор насељавао у Бачку Русине гркокатолике с намером да преко њих преводи православне Србе на унију, односно да је то била далекосежна политика Бечког двора и Римске курије. ${ }^{20}$ Не улазећи дубље у полемику са овим становиштем, треба истаћи да до данас нико није изнео чврсте доказе да је Редл добио налог од виших коморских или државних власти да у Бачку насељава Русине гркокатолике, нити да је од споменутих власти тражио дозволу за насељавање Русина унијата. Коначно, и сама чињеница да је у Бачку до краја 18. века насељено свега око 2000-2500 Русина гркокатолика без посебних привилегија и материјалне подршке јасно указује да они нису представљали снагу која је могла да уради нешто на плану унијаћења православних Срба.

\footnotetext{
народно предање о досељавању Русина у Крстур 1751-1752. године, у ком се наводи да је једна група, пошто их је затекла зима, презимили у Макоу, а у пролеће су кренули у Крстур; György Juhász , Emlék o mákoi gör. kath. templom felszentelési 100-ik évfordenlojának jubileumára, Makó 1878, 6. Ту се наводи да се гркокатолички свештеник Михајло Кевежди са 40 породица преселио из Макоа у Крстур.

${ }^{16}$ Федор Лабош, нав. дело, 190: изјаве дате пред судским властима у Крстуру 1757. године: изјава Пеће Раца: 192: изјава Јоана Бесермењија.

${ }^{17}$ Приликом боравка у Макоу у јесен 2010. и прегледајући матичне књиге рођених, умрлих и венчаних у архиву гркокатоличке парохије уверио сам се да су кроз цео 18. и 19 век постојала словенска презимена: Алекса, Козма, Петрович, Попович, Сонкович, Шмајда и многа друга.

18 Јанко Рамач, Иитван Удвари у историографији Русина, Извори о историји и култури Војводине, Зборник радова 2, Филозофски факултет у Новом Саду - Одсек за историју, Нови Сад 2010, 216.

${ }^{19}$ Федор Лабош, нав. дело, 64

${ }^{20}$ Vladimir Biljnja, Rusini u Vojvodini - Prilog izučavanju istorije Rusina Vojvodine (1918-1945), Dnevnik, Novi Sad 1987, 18-19.
} 
Текст контракта о насељавању Русина у Крстур из 1751. године Лабош преузима од Хавријила Костељника ${ }^{21}$ и, поредећи га са контрактом о насељавању Немаца у Гајдобру, закључује да разлике у њима проистичу из чињенице да су Немци насељавани на основу царског декрета, а Русине је насељавала локална коморска администрација. Због тога је контракт о насељавању Немаца много повољнији од оног по ком су насељавани Русини у Крстур 1751. и у Куцуру 1763. године. ${ }^{22}$ Лабош наводи да су први русински досељеници радили на обрађивању земље коју су касније добили Немци, као и на подизању кућа за немачке колонисте, али не наводи одговарајуће изворе. ${ }^{23}$

Лабош спомиње да је приликом канонске визитације 14. аугуста 1767. године (вероватно мисли на гркокатоличку парохију у Куцури) у Обровцу забележено неколико гркокатолика, али је парох опозван због малог броја верника. У Обровцу је 1764. године било 25 гркокатоличких породица, укупно око 100 душа. Он сматра да су се они преселили у Крстур, али у документу на који се позива о томе се ништа не говори. ${ }^{24}$ Калочки архиепископ Јожеф Баћањи је у почетку одуговлачио и одбијао да за Русине који су се 1763. године почели насељавати у Куцуру оснује посебну гркокатоличку парохију док они живе у једном насељу са православним Србима, сматрајући да је најбоље решење да се или Срби или Русини преселе у друго насеље и да се тако формирају верски чиста насеља. ${ }^{25}$ Крајем седамдесетих година 18. века коморска администрација у Бачкој, под притиском извесног броја русинских породица из Крстура и Куцуре да им Комора додели нове површине обрадивог земљишта због великих поплава у њиховим атарима, обратила се Угарској дворској комори да ова издејствује код царице Марије Терезије дозволу за пресељавање Русина из Куцуре у Обровац, а Срба из Обровца у Куцуру, или Срба из Куцуре у Обровац, а Русина из Обровца у Куцуру. На крају је коморска администрација у Бачкој добила сагласност да Србе из Куцуре пресели у Обровац, а Русине из Обровца у Куцуру. ${ }^{26}$ Ипак, у пописима гркокатоличке парохије у Куцури из 1810. и 1825. године у Обровцу се спомиње мањи број Русина. ${ }^{27}$

Лабош је свом рукопису приложио велики број копија оригиналних докумената на које се позива. Нажалост, мада се у фуснотама често наводи да се прилаже копија документа или копија са преводом текста са латинског језика на русински, у књизи најчешће није објављена ни копија, а понекад ни наведени превод документа. Разлог необјављивања тих прилога није познат, али се може претпоставити да издавач, пошто је књига објављена после смрти Ф. Лабоша, без његових упутстава и интервенција није урадио како је то он замислио и припремио

\footnotetext{
${ }^{21}$ Гавриїл Костельник, Liber тотоrabilium грекокатолїикей парохиї бачкерестурскей, Нови Сад 1998, 29-30.

${ }^{22}$ Федор Лабош, нав. дело, 65-66.

${ }^{23}$ Исто, 67.

${ }^{24}$ Исто, 69.

${ }^{25}$ Янко Рамач, Руснаци у Южней Угорскей (1745-1918), Нови Сад 2007, 118.

${ }^{26}$ Борис Холошняй, Закладанє Бечского двора за ришованє економских и иерковних почежкосцох бачванских Руснацох 70-тих рокох ХVIII столїтия, Руски календар 1998, Нови Сад 1997, 83-85.

${ }^{27}$ Славко Гавриловић, нав. дело, 180: 1810. године у Обровцу је било 14, а 1825 - 12 гркокатолика.
} 
за штампање. Сам Лабош је у неколико наврата спомињао да је после Другог светског рата из бившег коморског архива у Сомбору добијао многе оригиналне документе који су остали у његовом власништву. Тако су можда заувек изгубљени бројни оригинални документи које је Лабош користио и имао у својој збирци. За истраживаче то је велики губитак.

У старијој мађарској историографији о Русинима у Бачкој наводи се да се у Куцуру 1765. године населила 41 русинска породица, и $1767-42$ породице, ${ }^{28}$ а ове податке су касније преузимали и други аутори. Лабош наводи да се у Куцуру 1763. године населила само 41 породица, мада је контрактом било предвиђено да се насели 150 породица, ${ }^{29}$ и сматра да су се многи од оних који су дошли у Куцуру, незадовољни ондашњим приликама, населили у Крстур. ${ }^{30}$ Даље наводи да је коморска администрација, незадовољна малим бројем Русина који су се населили у Куцуру, наставила да врбује нове досељенике из североисточних жупанија Угарске, али и тада су дошле само 42 породице. ${ }^{31}$ Разлог слабом одазиву Русина из горњих крајева Мађарске у Куцуру Лабош види у чињеници да је куцурски атар био доста водоплаван и да је ту била нездрава клима. ${ }^{32}$

Лабош доста нашироко приказује расправу на жупанијском коморском суду у Сомбору 1767. године поводом неких корекција Трауновог урбара из 1736. године. ${ }^{33}$ Ту он описује привредне прилике и обавезе сељака на коморским имањима у Бачкој до увођења урбара М. Терезије из 1767. године. И мада ништа не спомиње о увођењу овог урбара у Крстуру и Куцури 1772. године, наводи у преводу неколико урбаријалних контраката за Крстур и Куцуру почев од 1785. до 1792-95. године, у којима су подробно наведене сва давања и обавезе поданика према Комори као и начин њихових плаћања, односно испуњавања. ${ }^{34}$ Подаци о свим задужењима поданика у готовом новцу и у радној ренти, као и неизмирена дуговања пренета за следећу/следеће године, много говоре о положају и животу поданика. Аутор даје податке и о оновременим мерама за тежину, запремину и течности, што обичном читаоцу олакшава сналажење у шаренилу коришћења различитих мера. Слику о свакодневном животу употпуњавају и ценовници прописаних цена за поједине прехрамбене артикле, као и цене надница за обављање појединих послова за мушкарце, жене и децу.

\footnotetext{
${ }^{28}$ Gyula Dudás, Bacs-Bodrog vármegye egyetemes monografiája, t. II, Zombor 1896, 406; Samu Borovszky, Bacs Bodrog vármegye, t. I, Budapest 1909, 102.

${ }^{29}$ Федор Лабош, нав. дело, 76-77.

30 Исто, 77; Мирон Жирош, нав. дело, 59-62. Ту Жирош показује на основу података пописа становништва Крстура и Куцуре да су се од 1763. године многе русинске породице из Крстура преселиле у Куцуру.

31 Федор Лабош, нав. дело, 77. Ту Лабош не наводи никакве доказе о поновном врбовању нових русинских колониста у североисточним жупанијама Угарске ради пресељавања у Бачку, у Куцуру.

32 Федор Лабош, нав. дело, 77.

${ }^{33}$ Исто, 84-105; Пун текст Трауновог урбара из 1736. године објављен је у целини: Славко Гавриловић Иван Јакшић, Грађа за привредну и друштвену историју Бачке у XVIII веку, Београд 1986, 1- 7: Dispositio Trauniana.

${ }^{34}$ Федор Лабош, нав. део, 107-139; Ове урбаријалне контракте доста нашироко коментарише и Славко Гавриловић: у наведеном делу, 167-169.
} 
Аутор у посебном поглављу говори о обавези сељака да плаћају контрибуцију, коју су некад плаћали у новцу, некад у натури, а често издржавањем извесног броја војника, њихових официра и коња. Ове обавезе су становништву нарочито тешко падале у време неродних година, када људи често од својих приноса нису имали довољно да прехране себе и своју стоку, а морали су да испуњавају и све обавезе према Комори, жупанији и да плаћају контрибуцију. У том поглављу аутор прилаже спискове сеоских кнезова/бирова и присежника у Крстуру и Куцури за поједине године у другој половини 18. и у првој половини 19. века и описује њихове дужности и обавезе у убирању разних давања и испуњавању обавеза према државним властима и властелину. Због неиспуњавања или кашњења са испуњавањем обавеза сеоски кнезови су понекад били јавно кажњавани и понижавани, да би послужили као пример кажњавања свакога ко не испуњава обавезе или не поштује власт. ${ }^{35}$ Ту је описан начин функционисања судова у оквиру жупанија и срезова, који су увек били више у служби власти и племства, а мање су штитили права поданика.

Посебну пажњу Лабош посвећује положају коморских поданика у Крстуру и Куцури седамдесетих и осамдесетих година 18 . века, када су због честих и обилних киша, нижи делови атара и насеља били плављени. Тих година делови атара су остајали необрађени или би посејани усеви пропадали, ливаде се нису могле косити, а и велики делови пашњака су били под водом. Од воде и велике влаге многе куће од набоја су пропадале и рушиле се. То је за Русине у Крстуру и Куцури био изузетно тежак период, када су многи размишљали да се врате у стари завичај или да се преселе у друга насеља. Ове две општине су се често обраћале коморским и жупанијским властима тражећи помоћ и заштиту: молили су да им део обавеза у новцу и натури буде смањен због немогућности да користе земљиште које су од Коморе добили на уживање, и да им она додели нове површине обрадивог земљишта, ливада и пашњака, наводећи да многи становници живе у великој беди или на ивици глади. У тим молбама су се позивали на тачке контраката о насељавању у Крстур односно Куцуру, у којима је било наглашено да уколико се број становника у селима толико увећа да ће им недостајати земљишта, Комора ће им доделити нове површине из суседних пустара. Ту Лабош у преводу на русински наводи неколико таквих молби упућених коморским властима и жупанији, и молбу упућену цару Фрањи I 1794. године. ${ }^{36}$

Поглавље о верским односно црквено-религијским приликама у Крстуру и Куцури у другој половини 18. века пружа богатство веома значајних података не само из те области, него и у вези са насељавањем Русина у Бачку пре почетка организованог насељавања на основу контракта 1751. године. Истина, Лабош износи неке тврдње које нису поткрепљене одговарајућим изворима: наводи да је монах Иларион Прусицки стигао у Крстур са првом групом досељеника 1751.

\footnotetext{
${ }^{35}$ Федор Лабош, нав. дело, 150-151.

${ }^{36}$ Исто, 156-181; Славко Гавриловић, нав. дело, 170-171. Ту се Гавриловић углавном позива на податке из Лабошевог рукописа.
} 
године, ${ }^{37}$ мада до данас није утврђено када и одакле је стигао и када је отишао из села или умро.

Лабош сматра да сам начин насељавања Русина у Бачку средином 18. века довољно јасно указује да оно нема никакве везе са верском политиком Бечког двора о превођењу православних на унију и да страх православних Срба од Русина и њихових активности на пољу унијачења није био оправдан. Ипак, лоша искуства због ранијих покушаја власти и католичке цркве у превођењу на унију научила су православне Србе да увек буду на опрезу и добро организовани. Због тога није чудно да су реаговали одмах на почетку досељавања Русина гркокатолика и да су православни свештеници настојали да их преведу на православну веру, у чему су имали подршку своје црквене хијерархије. Калочка архиепископија, под чијом црквеном јурисдикцијом су били Русини гркокатолици у Бачкој, свим средствима је настојала да онемогући њихове контакте са православнима да би на тај начин смањила могућност њиховог преласка на православну веру. ${ }^{38}$

У историографији о Рисинима у Јужној Угарској питање верских сукоба између православних и гркокатолика у Крстуру педесетих година 18. века заузима значајно место, и о њему су писали, поред Ф. Лабоша, Евгеније Џуња, 39 Јаким Сабадош, ${ }^{40}$ Славко Гавриловић ${ }^{41}$ и Јанко Рамач. ${ }^{42}$ Овде ћемо у најкраћем показати шта је допринос Ф. Лабоша у изучавању овог питања. Сукоби између православних и гркокатолика у Крстуру почели су када су православни предузели кораке да подигну властиту цркву и тражили за то дозволу од православног митрополита у Сремским Карловцима и коморске администрације. У селу су отпочели сукоби између припадника две конфесије, а вести о сукобима су стигли и до царице Марије Терезије. Уследила су испитивања окривљених за изазивање сукоба и потписника молбе за доволу подизања православне цркве. Лабош је објавио изјаве већег броја сељака, претежно оних који су прешли на православну веру, пред жупанијском комисијом. Ове изјаве дају изузетно богату лепезу података не само о црквенорелигијским питањима него и току досељавања Русина у Бачку. Из грађе коју Лабош прилаже у преводу на русински језик јасно се може пратити ток догађаја. Русински досељеници који су стигли у Бачку пре почетка организованог насељавања у Крстур 1751. године овде нису имали гркокатоличког свештеника. Зато су неки почели да одлазе на богослужења у православне цркве, а касније су тамо одлазили и на исповед и причест. То је био први контакт русинских досељеника са православнима у овим крајевима. После насељавања Русина у Крстур у село су код православних Русина почели да долазе православни свештеници, који су их храбрили да остану у православној вери обећавајући да ће имати сваку помоћ

\footnotetext{
${ }^{37}$ Федор Лабош, нав. дело, 182.

${ }^{38}$ Исто, 186.

${ }^{39}$ Евгениј Џуња, О досељењу првих Русина у Војводину и њиховом животу, Годишњак Историјског друштва Војводине, Нови Сад 1951, 47-53.

40 Яким Сабадош, Походзенє и приход Руснацох до Бачкей, Шветлосц, 3, 4, Нови Сад 1954, 193-204, 269280.

${ }^{41}$ Славко Гавриловић, нав. дело, 157-163.

42 Јанко Рамач, нав. дело, 131-142.
} 
и заштиту Карловачке митрополије. Тада су отпочели сукоби између православних и гркокатолика у селу. Лабош приказује како се у разрешавање ових сукоба укључују представници Калочке архиепископије, Бачке жупаније, коморске администрације и Бачке епископије, односно Карловачке митрополије. Свака од заинтересованих страна је имала своју истину: представници Калочке архиепископије, Бачке жупаније и коморске администрације позивали су се на контракт о насељавању Русина у Крстур у ком је било јасно наглашено да се у то коморско насеље могу насељавати само Русини гркокатолици. Православна митрополија се увек позивала на Привилегије православних Срба и указивала је на притиске којима су били изложени они гркокатолици који су прешли на православну веру. На крају је пресудила политичка моћ и власт: Калочка архиепископија и Бачка жупанија су имале механизме власти, а то је подразумевало затворске казне и физичка кажњавања за „преступнике“, да Русине апостате врате у крило гркокатоличке цркве. Малобројни појединци, који су желели да остану у православној вери, преселили су се у нека суседна православна насеља и временом се потпуно асимиловали. Лабош на основу приложене грађе закључује да је страх од казни највише утицао на многе који су прешли на православну веру да се врате у гркокатоличку цркву. ${ }^{43}$ Славко Гавриловић је у изучавање овог питања укључио и грађу православне провенијенције и на тај начин допринео да оно буде целовитије сагледано. $^{44}$

Лабош у својој књизи објављује низ докумената преведених са латинског на русински језик који пружају мноштво података о привредном животу и економском положају коморских поданика у Крстуру и Куцури у другој половини 18. и првој половини 19. века. Ту су пописи становника са детаљним подацима о појединим домаћинствима, о броју чланова породица и свих који живе у једном домаћинству, о броју ситне и крупне стоке, запрежне стоке, површинама обрадивог земљишта и ливада које домаћинства користе, о броју способних за рад у сваком домаћинству итд. ${ }^{45}$ Богатство података пружају и објављени тестаменти, из којих се јасно види материјално стање појединих породица и пракса како је уређивано наслеђивање после смрти родитеља. ${ }^{46}$

У кратком осврту на прилике 1848. године Лабош наводи да је русинска интелигенција, претежно гркокатоличко свештенство, школовано углавном у Загребу, више била оријентисана на Хрвате и због тога није током револуције подржавала мађарску револуцију. ${ }^{47}$ Ипак, новија истраживања показују и другу страну у овим догађајима: незадовољни својим подређеним положајем у оквиру Крижевачке епархије, у којој су Русини чинили $2 / 3$ верника, русински свештеници из Бачке су у лето 1848. године упутили управи Крижевачке епархије захтев у ултимативном облику у ком су тражили да Русини у свему буду равноправни са

\footnotetext{
${ }^{43}$ Федор Лабош, нав. дело, 186-197.

${ }^{44}$ Славко Гавриловић, нав. дело, 157-163.

45 Федор Лабош, нав. дело, 209-216.

${ }^{46}$ Исто, 220-229.

${ }^{47}$ Исто, 231 -232.
} 
Хрватима и да остварују своја неприкосновена национална права, упозоравајући крижевачког епископа да ће, ако не добију позитиван одговор за месец дана, исти захтев проследити мађарској револуционарној влади и тражити да буду издвојени из Крижевачке епархије и прикључени једној од две гркокатоличке епархије у североисточној Угарској - Мукачевској или Прешовској. ${ }^{48}$

Лабош је забележио сећања људи из Куцуре о приликама 1848. године: после борби крајем јануара и на почетку фебруара 1849. године, када је српска војска ослободила Бачку, људи из Куцуре су давали храну српској војсци. Ту се не наводи да ли су неки Русини били у српској војсци, ${ }^{49}$ али је познато да је известан број Русина из Крстура и Куцуре био у мађарским хонведима. ${ }^{50}$ Лабош наводи и предање које је дуго било присутно међу Русинима у Бачкој као колективно уверење да они нису страдали у револуцији, јер је руски цар „упозорио“ војске да он у Јужној Угарској има два снопа свог народа - Крстур и Куцуру - којима се ништа не сме десити. ${ }^{51}$

Пре Лабоша етнографске описе Русина у Бачкој објавили су Михајло Врабељ, Володимир Хнатјук, Иштван Франкл, Ристо Јеремић и други, али Лабошев опис неких русинских народних обичаја и народне ношње показује да је добро познавао народни живот и није правио грешке које су у оваквим описима карактеристичне за оне који недовољно знају народ и његове обичаје и све посматрају са стране. ${ }^{52}$

Поглавље о црквеном и просветном животу Русина добрим делом је урађено на основу Хронике Руског Крстура Хавријила Костељника, ${ }^{53}$ мада се Лабош понекад позивао и на изворе из Архива Калочке архиепископије, углавном оне које је користио и Костељник. Делове о раду конфесионалних школа у Крстуру и Куцури у другој половини 19. века Лабош је писао на основу сећања старијих људи. У том поглављу су дате информације о активностима русинских средњошколаца четрдесетих година 19. века у оквиру „Илирског друштва“ у Гркокатоличкој семинарији у Загребу.

На крају треба рећи да Федор Лабош својим делом, поред Хавријила Костељника, заузима значајно место у историографији Русина у Јужној Угарској до 1918. године. Чак је и судбина њихових рукописа била слична, јер су дуго чекали на објављивање и у међувремену били интензивно коришћени од стране истраживача. Истина, међу Русинима у Војводини Лабошева књига је у време њеног објављивања

\footnotetext{
48 Јанко Рамач, нав. дело, 280-284.

${ }^{49}$ Федор Лабош, нав. дело, 231-232.

50 Михаил Врабель, Русин на долині Бачванскй, Календар 1891, Ужгород 1890, 80-86.

${ }^{51}$ Федор Лабош, нав. дело, 232.

${ }^{52}$ Исто, $236-242$.

53 Хавријил Костељник је свој рукопис под насловом Liber meтorabilium грекокатолїщкей парохиї бачкерестурскей написао у Руском Крстуру 1915. године. Рукопис је годинама чуван необјављен, а у периоду између два светска рата делови тог рукописа су били објављивани у Русинском календару који је издавало Русинско народно просветно друштво. Лабош је користио управо те објављене делове Костељникове Хронике Крстура и на њих се позива. Интегрални текст овог рукописа штампан је тек крајем прошлог века: Гавриїл Костельник, Liber тетоrabilium грекокатолїикей парохиї бачкерестурскей, Нови Сад 1998, 218.
} 
примљена с извесном дозом резерви из политичких разлога, јер је објављена од стране Савеза Русина и Украјинаца Хрватске, који није имао симпатије међу комунистичком русинском елитом у Војводини. Међутим, свако ко се иоле озбиљније интересовао за прошлост Русина на овим просторима или је изучавао, није могао да заобиђе дело Федора Лабоша због богатства фактографског материјала и изузетно значајних прилога који су углавном објављени у преводу. Нажалост, у књизи нису објављене копије тих докумената, иако је Лабош у фуснотама наводио да их прилаже рукопису. Славко Гавриловић је користо Лабошев рукопис пре његовог објављивања и у две речи дао о њему прецизну оцену рекавши да је рађен доста „трезвено и објективно“.

\section{Извори и литература:}

Извори:

Гавриловић, Славко, Јакшић Иван, Грађа за привредну и друштвену историју Бачке у XVIII веку, Београд, 1986.

Државни архив у Будимпешти (Országos levéltár, Budapest), E-25, Informationes Cameralis administrationis Bacsiensis, Redl - Извештај коморског администратора Редла Угарској дворској комори.

Литература:

Biljnja, Vladimir, Rusini u Vojvodini - Prilog izučavanju istorije Rusina Vojvodine (1918-1945), Dnevnik, Novi Sad, 1987.

Borovszky, Samu, Bacs Bodrog vármegye, t. I, Budapest, 1909.

Врабель, Михаил, Русин на долині Бачванскй, Календар 1891, Ужгород, 1890, 80-86.

Vranešević, Branislav, Rusini u borbi za nacionalni opstanak 1848-1890, Godišnjak Društva istoričara Vojvodine, Novi Sad, 1977, 217-253.

Gavrilović, Slavko, Rusini u Bačkoj i Sremu od sredine XVIII do sredine XIX veka, Godišnjak Društva istoričara Vojvodine, Novi Sad, 1977, 153-215.

Гнатюк, Володимир, Руски населєня у Бачкей, у: Володимир Гнатюк, Етнотрафски материяли з Угорскей Руси, т. V, Руске слово, Нови Сад, 1988, 78-126.

Dudás, Gyula, Bacs-Bodrog vármegye egyetemes monografiája, t. II, Zombor, 1896, 406; Samu Borovszky, Bacs Bodrog vármegye, t. I, Budapest, 1909.

Gaćeša, Nikola, Rusini između dva svetska rata, Godišnjak Društva istoričara Vojvodine, Novi Sad, 1977, 275-306.

Жирош, Мирон, Бачванско-сримски Руснаци дома и у швеце 1745-1991, т. I, Нови Сад, 1997.

Juhász, György, Emlék o mákoi gör. kath. templom felszentelési 100-ik évfordenlojának jubileumára, Makó, 1878.

Костельник, Гавриїл, Liber тотоrabilium грекокатолӥикей парохиї бачкерестурскей, Нови Сад, 1998.

Лабош, Федор, История Русинох Бачкей, Сриму и Славониї 1745-1918, Союз Русинох и Українцох Горватскей, Вуковар, 1979, 299.

Lebl, Arpad, Rusini od 1890. do 1918, Godišnjak Društva istoričara Vojvodine, Novi Sad, 1977, 255-273. 
Palić, Milenko, Rusini u radničkom pokretu do 1941. godine, Godišnjak Društva istoričara Vojvodine, Novi Sad, 1977, 309-328.

Рамач, Янко, Руснаци у Южней Угорскей (1745-1918), Нови Сад, 2007.

Сабадош, Яким, Походзенє и приход Русначох до Бачкей, Шветлосц, 3, 4, Нови Сад, 1954, 193-204, 269-280.

Тимко, Онуфриј, Насељеници Руског Крстура и Куцуре, Зборник Матице српске за друштвене науке, бр. 50, Нови Сад, 1968, 130-142.

Борис, Холошняй, Закладанє Бечского двора за ришованє економских и церковних почежкосцох бачванских Руснацох 70-тих рокох XVIII столїтия, Руски календар 1998, Нови Сад, 1997, 82-92.

Џуња, Евгеније, О досељењу првих Русина у Војводину и њиховом животу, Годишњак Историјског друштва Војводине, Нови Сад, 47-53. 


\title{
FEDOR LABOŠ AND HIS WORK IN THE HISTORIOGRAPHY ON RUTHENIANS IN THE SOUTHERN HUNGARY
}

\begin{abstract}
Summary
The author critically examined the History of Ruthenians in Backa, Sirmium and Slavonia (1745-1918), wrote by Fedor Laboš. It had an important place in the historiography of the Ruthenians in the Southern Hungary, not only because it was the first history written by a Ruthenian author, which covered the history of Ruthenians from their arrival to this region until 1918, including a review of their past before settling in Backa, but also because of the fact that the author used very rich historical material, which was partially lost or inaccessible to the researchers.
\end{abstract}

Keywords: Fedor Laboš, historiography of Ruthenians, Russians in the Southern Hungary, Greek Catholics, Orthodox. 